\title{
Gaya Kepemimpinan, Kedisiplinan, dan Motivasi terhadap Kinerja Karyawan
}

\section{Lenni Lestari Situmorang1, Mas Intan Purba², Kathree Moliyana Naibaho ${ }^{3}$, Meiliana Sinaga ${ }^{4}$ Rotua Roulina ${ }^{5}$}

1,2,3,4,5 Program Studi Manajemen, Fakultas Ekonomi, Universitas Prima Indonesia, Indonesia

\begin{abstract}
ABst:
Keywords:

Leadership;

Discipline;

Motivation;

Employee

Performance

Abstract: The purpose of this research is to analyze the impact of leadership style, discipline, and motivation on employee performance gradually and simultaneously. This research approach is done quantitatively. The population for this study consisted of all 70 employees. The sampling method with Non Probability sampling is a saturated sample of 30 people. Data collection techniques in this study are interviews, questionnaires, and documents. Data analysis in this study used qualitative data analysis and quantitative analysis through descriptive and inferential statistics. The results showed that the leadership style (X1) has a tcount value of -0.139 and a ttable value of 2.028 , so the tcount $<$ ttable $(-0.139<2.028)$ with a significant value of $0.890>0.05$. Discipline (X2) with a tcount value of 3.985 and a t-table value of 2.028 , the value of tcount $>$ ttable $(2,985>2,028)$ and the significance of $0.000<0.05$. Motivation (X3) with a tcount value of 1.435 and a ttable value of 2.028 , the value of tcount < ttable $(1.435<2.028)$ with a significant value of $0.160>0.05$. then, it can be concluded that the leadership style variable has a negligible and insignificant effect on employee performance, the discipline variable has a positive and significant effect on employee performance, and motivation has no or no significant effect on employee performance. The implications of the research are expected to provide an evaluation in improving employee performance.
\end{abstract}

\section{Kata kunci:}

Kepemimpinan; Kedisiplinan;

Motivasi;

Kinerja

Karyawan

Abstrak: Tujuan penelitian ini untuk menganalisis dampak gaya kepemimpinan, disiplin, dan motivasi terhadap kinerja karyawan secara bertahap dan serentak. Pendekatan penelitian ini dilakukan secara kuantitatif. Populasi untuk penelitian ini terdiri dari seluruh 70 karyawan. Metode pengambilan sampel dengan Non Probability sampling ialah sampel jenuh yang berjumlah 30 orang. Teknik pengumpulan data dalam penelitian ini yaitu wawancara, kuesioner, dan dokumen. Analisis data dalam penelitian ini menggunakan analisis data kualitatif dan analisis kuantitatif melalui statistika deskriptif dan inferensial. Hasil penelitian menunjukkan bahwa gaya kepemimpinan $\left(X_{1}\right)$ memiliki nilai thitung -0.139 dan nilai $t_{\text {tabel }}$ yakni 2.028 maka nilai thitung $<$ tabel $(-0.139<2.028)$ dengan nilai signifikannya $0.890>0.05$. Kedisiplinan $\left(\mathrm{X}_{2}\right)$ dengan nilai thitung 3.985 dan nilai $t_{\text {tabel }} 2.028$ maka nilai $t_{\text {hitung }}>t_{\text {tabel }}$ $(2.985>2.028)$ dan signifikannya $0.000<0.05$. Motivasi $\left(X_{3}\right)$ dengan nilai thitung 1.435 dan nilai ttabel yakni 2.028 maka nilai thitung $<$ tabel $(1.435<2.028)$ dengan nilai signifkannya $0.160>0.05$. Dapat disimpulkan bahwa variabel gaya kepemimpinan memiliki pengaruh yang dapat diabaikan dan tidak signifikan pada kinerja karyawan, variabel disiplin memiliki pengaruh positif dan signifikan pada kinerja karyawan, dan motivasi tidak berpengaruh atau tidak signifikan pada kinerja karyawan. Implikasi penelitian diharapkan dapat memberikan evaluasi dalam meningkatkan kinerja karyawan.

\section{Alamat Korespondensi:}

E-mail: masintapurba84@gmail.com (Situmorang)

\section{Pendahuluan}

Globalisasi menyebabkan tingkat persaingan ekonomi global antarperusahaan semakin ketat dan kompetitif, sehingga perusahaan perlu meningkatkan kualitas kerjanya agar tidak tertinggal dari yang lain (Azzahrati, 2018; Gailea et al., 2018). Sumber Daya Manusia (SDM) memiliki peran amat

$\begin{array}{ll}\text { History: } & \\ \text { Received } & \text { : 06 Maret } 2021 \\ \text { Revised } & : \text { 10 Maret } 2021 \\ \text { Accepted } & : \text { 16 Juni } 2021 \\ \text { Published } & : \text { 25 Juli } 2021\end{array}$

Publisher: Undiksha Press

Licensed: This work is licensed under a Creative Commons Attribution 3.0 License

Published : 25 Juli 2021 
penting karena keberhasilan suatu perusahaan ditentukan oleh sumber daya manusia (Alhusaini et al., 2020; Gandung \& Suwanto, 2020; Widelia et al., 2016). Untuk menjamin bahwa operasi manajemen berjalan lancar, perusahaan harus memiliki karyawan dengan potensi dan kemampuan hebat yang mampu mengelola organisasi dengan sukses untuk membantu meningkatkan produktivitas tenaga kerja. Jika kinerja karyawan meningkat, pendapatan perusahaan akan naik, yang akan memungkinkan perusahaan untuk bertahan di lingkungan bisnis yang berubah (Faustyna \& Jumani, 2018).

PT. Pancakarsa Bangun Reksa didirikan pada tahun 2009 merupakan salah satu perusahaan jasa konstruksi. Produk yang dihasilkan oleh perusahaan ini sudah banyak terjual di berbagai daerah di Indonesia bahkan telah di ekspor ke luar negeri. PT. Pancakarsa Bangun Reksa saat ini bersaing dengan perusahaan konstruksi nasional dengan mematuhi standar kualitas sepanjang proses produksi dan dengan menggunakan sumber daya yang kompetitif. Permasalahan yang terjadi yaitu hubungan antara pemimpin dengan karyawanya masih kurang harmonis dan kurang tegasnya atasan terhadap bawahan dalam menyelesaikan pekerjaan, sehingga karyawan kurang memahami tujuan dari pekerjaan yang dijalankannya. Hal ini berakibat kepada kinerja karyawan yang menurun dan hasil kerja yang tidak seusai dengan target kerja yang telah ditetapkan. Kinerja karyawan menjadi salah satu elemen yang berkontribusi pada kesuksesan perusahaan. Tanpa kinerja dan kualitas karyawan yang kuat, perusahaan tidak akan dapat mencapai tujuannya. Kinerja karyawan dapat dinilai dengan memeriksa seberapa efektif mereka menjalankan tugas dan tanggung jawab yang ditetapkan. Jika kinerja karyawan hebat, itu akan mencerminkan positif pada hasil perusahaan. jika buruk, hasil perusahaan akan sama-sama tidak menguntungkan (Farhah et al., 2020; Mahriani, 2018; Widyawati \& Karwini, 2018). Ada banyak faktor yang mempengaruhi kinerja perusahaan, di antaranya adalah gaya kepemimpinan, disiplin, dan motivasi (Prabowo, 2019; Rofiliana \& Rofiuddin, 2021).

Pendekatan seorang pemimpin untuk memanfaatkan pekerja secara efektif untuk mencapai tujuan perusahaan disebut sebagai gaya kepemimpinannya (Azzahrati, 2018; Cahyadi, 2019). Oleh karean itu, gaya kepemimpinan sangat memengaruhi kinerja karyawan. Keberadaan seorang pemimpin sangat dibutuhkan dalam memotivasi atau mendorong karyawannya untuk lebih semangat lagi dalam bekerja (Avilla, 2018; Gandung \& Suwanto, 2020; Sudarso, 2017). Seorang pemimpin harus menginspirasi, optimisme, kreativitas, berbagi komitmen, dan bertumbuh dalam situasi yang baik maupun buruk (Ariyani, 2016; Nugroho, 2019). Ketika kepemimpinan menggunakan gaya kepemimpinan yang sesuai dan diterima oleh semua pekerja, lingkungan kerja yang luar biasa dapat dibuat (Hardono, Haryono, 2017; Hasibuan, 2019). Selain itu, bagi perusahaan, disiplin kerja sangat penting. Oleh sebab itu, perusahaan menetapkan berbagai aturan yang harus ditaati oleh seluruh karyawan seperti menaati ketentuan jam kerja, melakukan tugas atau pekerjaan dengan baik, berkerja dengan tertib. Namun demikian, masih banyak ditemukan karyawan yang tidak menaati peraturan kedisiplinan yang telah ditetapkan oleh perusahaan. Masih banyak kayawan yang tidak mengahargai waktu, misalnya datang terlambat dan bolos kerja tanpa alasan yang jelas (Faustyna \& Jumani, 2018; Istiqomah \& Suhartini, 2016). Kinerja juga diperngaruhi oleh motivasi. Motivasi merupakan faktor pendukung karyawan untuk melaksanakan suatu kegiatan atau pekerjaan. Dengan adanya motivasi, maka karyawan akan lebih semangat, rajin, proaktif dalam melaksanakan tugasnya (Istiqomah \& Suhartini, 2016; Siska, 2018). Seorang yang memiliki tingkat motivasi rendah juga cenderung malas dan tidak mempunyai semangat kerja menyebabkan kinerja yang dihasilkan tidak optimal. Oleh sebab itu, perusahaan perlu memerhatikan motivasi karyawan dengan melakukan upaya-upaya guna meningkatkan motivasi karyawan.

Temuan penelitian sebelumnya menyatakan gaya kepemimpinan akan berkaitan langsung dengan lingkungan kerja dalam berorganisasi yang akhirnya akan menimbulkan kinerja karyawan, sehingga terlihat adanya hubungan gaya kepemimpinan dan lingkungan kerja dengan kinerja karyawan (Azzahrati, 2018; Cahyadi, 2019). Kinerja Karyawan dapat diketahui setelah adanya penerapan disiplin kerja (Effendi \& Yogie, 2019; Faustyna \& Jumani, 2018). Ketidakdisiplinan akan mengakibatkan kinerja karyawan menurun, sehingga memengaruhi hasil kerja. Temuan lain menyatakan bahwa pemberian motivasi perlu ditingkatkan lagi karena motivasi cukup berpengaruh 
untuk mencapai kinerja dengan baik (Sari \& Masruroh, 2018; Sya'roni, Herlambang, T., \& Cahyono, 2018). Penelitian ini sebelumnya menunjukkan adanya pengaruh gaya kepemimpinan terhadap kinerja dan disiplin kerja terhadap kinerja karyawan. Keterbaharuan penelitian ini yaitu variable yang digunakan gaya kepemimpinan, kedisiplinan, dan motivasi. Maka, tujuan penelitian ini yaitu menganalisis pengaruh gaya kepemimpinan, kedisiplinan, dan motivasi terhadap kinerja karyawan dan motivasi terhadap kinerja PT. Pancakarsa Bangun Reksa. Adanya penelitian ini diharapkan menjadi evaluasi dalam meningkatkan kinerja karyawan.

\section{Metode}

Pendekatan penelitian ini dilakukan secara kuantitatif. Pendapat Sugiyono (2017:8) dengan positivisme, metode kuantitatif berusaha mengukur dan menyelidiki populasi/sampel. Cara menentukan sampel biasanya dilakukan secara acak. Pengumpulan data dengan kuesioner. Untuk menguji hipotesis digunakan analisis data yang bersifat kuantitatif. Populasi untuk penelitian ini terdiri dari seluruh 70 karyawan PT Pancakarsa Bangun Reksa Dana Medan. Metode pengambilan sampel dengan Non Probability sampling ialah sampel jenuh yang berjumlah 30 orang. Penelitian ini dilakukan di PT. Pancakarsa Bangun Reksa yang terletak di Jl. Bintang Terang Km 13.8, Gg Bintang No.95 Medan yang berlangsung pada tanggal 10 Februari 2020 sampai dengan selesai.

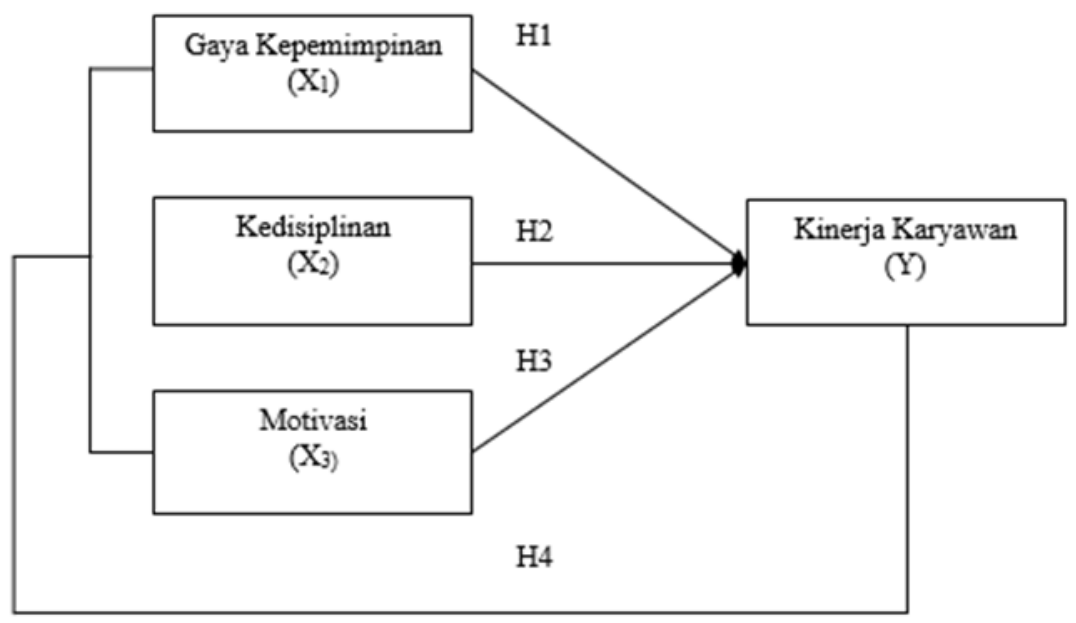

Gambar 1. Desain Penelitian Pengaruh Gaya Kepemimpinan, Kedisiplinan, Motivasi berdampak pada kinerja karyawan di PT Pancakarsa Bangun Reksa Medan

Teknik pengumpulan data dalam penelitian ini yaitu wawancara, kuesioner, dan dokumen. Wawancara dilakukan dengan bertanya langsung pada pemimpin PT Pancakarsa Bangun Reksa Medan. Kuesioner dengan skala likert berupa serangkaian pertanyaan kepada pekerja PT Pancakarsa Bangun Reksa Medan. Dokumen yang dikumpulkan berupa sejarah singkat perusahaan, struktur organisasi, dan jumlah karyawan yang ada di PT. Pancakarsa Bangun Reksa Medan. Adapun kisi-kiri kesioner yang diberikan kepada responden ada pada tabel 1.

Analisis data dalam penelitian ini menggunakan analisis data kualitatif dan analisis kuantitatif melalui statistika deskriptif dan inferensial. Instrument sebelum diberikan kepada responden dilakukan uji validitas dan reliabilitas. Uji validitas dipakai untuk mengetahui valid atau tidaknya sebuah angket. Apabila pertayaan pada angket bisa memprediksi objek penelitian, maka angket dapat dikatakan valid. Uji reliabilitas dilakukan dalam menguji angket yang menjadi parameter akan variabel. Hasil atas kuisioner konsisten maka angket/kuesioner tersebut dinyatakan mampu dan dapat diandalkan. Setelah diberikan kepada responden, kuesioner dianalisis dengan uji asumsi klasik terdiri dari uji normalitas, uji multikolinieritas, uji heterokedasitas. Uji hipotesis dilakukan dengan analisis regresi linier berganda. Analisis regresi linier ganda digunakan untuk memprediksi kondisi 
(naik dan turun) peningkatan dan penurunan nilai. Selanjutnya dilakukan uji secara parsial / Individual (Uji t). Uji t digunakan untuk memperlihatkan sejauh mana pengaruh variabel bebas yang digunakan untuk menjelaskan perubahan dalam variabel dependen $\mathrm{H}_{0}$. Dan Uji Simultan (Uji F) digunakan untuk melihat apakah seluruh variabel bebas dalam model memengaruhi variabel terikat secara simultan.

Tabel 1. Kisi-Kiri Instrument Kinerja Karyawan

\begin{tabular}{|c|c|c|}
\hline Jenis Variabel & Indikator & Skala \\
\hline $\begin{array}{l}\text { Gaya kepemimpinan } \\
\left(X_{1}\right)\end{array}$ & $\begin{array}{l}\text { 1. Kemampuan analisis } \\
\text { 2. Keberanian } \\
\text { 3. Komunikasi } \\
\text { 4. Kemampuan mendengar } \\
\text { 5. Ketegasan } \\
\text { Sumber: Kartono (2013:189) }\end{array}$ & Likert \\
\hline $\begin{array}{l}\text { Kedisiplinan } \\
\left(\mathrm{X}_{2}\right)\end{array}$ & $\begin{array}{l}\text { 1. Mematuhi peraturan } \\
\text { 2. Bekerja secara efisien } \\
\text { 3. Untuk mengambil tindakan korektif. } \\
\text { 4. secara tepat waktu } \\
\text { 5. Tepat waktu meyelesaikan tugas } \\
\text { Sumber: Simamora (2013:746) }\end{array}$ & Likert \\
\hline $\begin{array}{l}\text { Motivasi } \\
\left(X_{3}\right)\end{array}$ & $\begin{array}{l}\text { 1. Fasilitas } \\
\text { 2. Prestasi kerja } \\
\text { 3. Balas jasa } \\
\text { 4. Pengakuan } \\
\text { 5. Kondisi kerja } \\
\text { Sumber: Afandi (2018:29) }\end{array}$ & Likert \\
\hline $\begin{array}{l}\text { Kinerja } \\
\text { Karyawan } \\
\text { (Y) }\end{array}$ & $\begin{array}{l}\text { 1. Hasil kerja } \\
\text { 2. Inisiatif } \\
\text { 3. Ketepatan waktu } \\
\text { 4. Sikap } \\
\text { 5. Pengetahuan } \\
\text { Sumber: Nurdin \&Rohendi (2016) }\end{array}$ & Likert \\
\hline
\end{tabular}

\section{Hasil dan Pembahasan}

Pada penelitian yang dilakukan pada PT Pancakarsa Bangun Reksa Medan, variabel bebas (independen variabel) terlihat gaya kepemimpinan, kedisiplinan, dan motivasi, sedangkan kinerja karyawan menjadi variabel terikatnya. Hal ini terlihat pada tabel 2 di bawah ini. Statistik deskriptif berhubungan dengan data dapat digambarkan (dideskripsikan atau disimpulkan). Tabel 2 menjelaskan hasil pengukuran atas gaya kepemimpinan dengan rata-rata yakni 42,17, standar deviasinya 4.150. Variabel kedisiplinan dengan nilai rata-rata yakni 41,60, standar deviasinya 4,453. Variabel motivasi rata-rata 42,02, standar deviasinya 3,745. Kinerja karyawan rata-rata yakni 41,07, standar devasinya 3,970. Uji normalitas dilakukan dengan SPSS diperoleh hasil value Signya memiliki nilai yakni 0,200 >0,05. Hasil tersebut distribusinya normal melalui dua langka pengujian, yakni uji memakai grafik dan normal probability plot. Hasil pengujian dapat dilihat pada gambar 2 dan 3 di bawah ini. 
Tabel 2. Hasil Statistics Desckritive

\begin{tabular}{lrrrrr}
\hline \multicolumn{7}{c}{ IDescriptive Statisticsl } \\
\hline & NI & \multicolumn{1}{c}{ Minimum } & Maximum & Mean & IStd. Deviation \\
\hline GayaKepemipinan & 40 & 35,00 & 50,00 & 42,1750 & 4,15030 \\
Kedisiplinan & 40 & 36,00 & 50,00 & 41,6000 & 4,45375 \\
Motivasi & 40 & 36,00 & 50,00 & 42,0250 & 3,74500 \\
KinerjaKaryawan & 40 & 35,00 & 50,00 & 41,0750 & 3,97032 \\
Valid N (listwise) & 40 & & & & \\
\hline
\end{tabular}

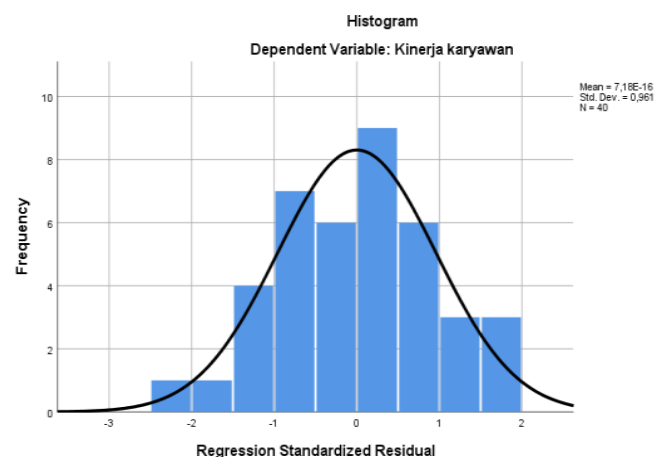

Gambar 2. Grafik Histogram

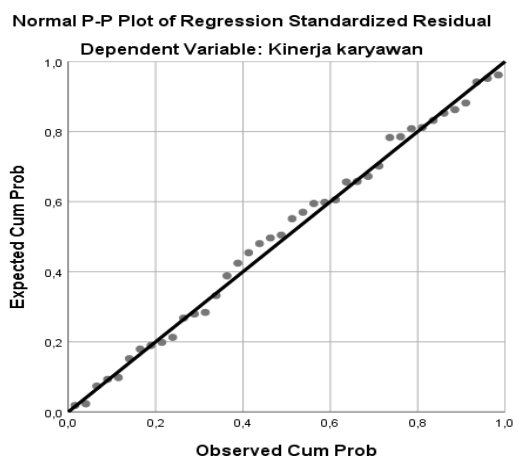

Gambar 3. Grafik normal P.P Plot Of Regresion Standardized Residul

Berdasarkan gambar 2 dan 3 di atas dapat dketahui bahwa tampilan gambar menunjukkan bahwa data penyebaran berada di garis diagonal serta mengiringi garis tersebut, sehingga data mempunyai distribusi normal. Pada grafik histogram melenceng ke kiri dan ke kanan. Ini berarti bahwa data berdistribusi normal.

Tabel 3. Hasi Uji Multkolineritas

\begin{tabular}{|c|c|c|c|}
\hline \multicolumn{4}{|c|}{ Coefficients $^{a}$} \\
\hline \multirow{2}{*}{\multicolumn{2}{|c|}{ Model }} & \multicolumn{2}{|c|}{ Collinearity Statistics } \\
\hline & & Tolerance & VIF \\
\hline \multirow[t]{4}{*}{1} & (Constant) & & \\
\hline & Gaya kepemimpinan & 0,307 & 3,253 \\
\hline & Kedisiplinan & 0,268 & 3,730 \\
\hline & Motivasi & 0,337 & 2,969 \\
\hline
\end{tabular}

a. Dependent Variable: Kinerja karyawan

Berdasarkan Tabel 3 dapat dilihat nilai tolerance tiap variabel bebas sebagai gaya kepemimpinan $=0,307$, kedisiplinan $=0,268$, dan motivasi $=0,337>0,1$. Nilai VIF setiap variabel independent sebesar gaya kepemimpinan $=3,253$, kedisiplinan $=3,730$, motivasi $=2,969$ kurang dari 10, sehingga data terkait terbebas dari mutikolinieritas. Uji Heterokesdastisitas menggunakan SPSS, sehingga diketahui data tersebar jauh dari 0 , data tidak memiliki heterokedastisitas, seperti yang ditunjukkan oleh distribusi poin yang tidak sama. Berdasarkan tabel 4 dapat dilihat ketiga variabel memiliki nilai asym.sig diatas 0,05. Artinya, gaya kepemimpin (X1) senilai 0,671 , kedisiplinan $\left(\mathrm{X}_{2}\right)$ senilai 0,631 , motivasi $\left(X_{3}\right)$ senilai 0.589 , dan pada data tersebut tidak terjadi gejala heterokedastisitas. 
Tabel 4. Hasil Uji Glejser

\begin{tabular}{llrrrrr}
\hline \multicolumn{7}{c}{ Coefficients $^{\mathbf{a}}$} \\
\hline
\end{tabular}

Tabel 5. Analisis Regresi Linier Berganda

\begin{tabular}{|c|c|c|c|c|c|c|}
\hline \multicolumn{7}{|c|}{ Coefficients $^{\mathrm{a}}$} \\
\hline & & $\begin{array}{l}\text { Unstan } \\
\text { Coeffi }\end{array}$ & $\begin{array}{l}\text { rdized } \\
\text { entsl }\end{array}$ & $\begin{array}{l}\text { Standardized } \\
\text { CoefficientsI }\end{array}$ & & \\
\hline \multicolumn{2}{|c|}{ Model } & B & Std. Error & Betal & $\mathbf{t}$ & Sig. \\
\hline \multirow[t]{4}{*}{1} & (Constant) & 6,929 & 4,072 & & 1,702 & 0,097 \\
\hline & Gaya kepemimpinan & 0,021 & 0,153 & 0,022 & 0,139 & 0,890 \\
\hline & Kedisiplinan & 0,608 & 0,153 & 0,682 & 3,985 & 0,000 \\
\hline & Motivasi & 0,232 & 0,162 & 0,219 & 1,435 & 0,160 \\
\hline
\end{tabular}

a. Dependent Variable: Kinerja karyawan

Dari penelitian ini terlihat ada tiga variabel bebas, yakni gaya Kepemimpinan, kedisiplinan, motivasi, dan satu variabel terikat yakni kinerja karyawan. Nilai konstanta sebesar 6,929 diartikan apabila ada variabel gaya kepeimpinan $\left(X_{1}\right)$, kedisiplinan $\left(X_{2}\right)$, serta motivasi $\left(X_{3}\right)=0$, maka performa karyawan akan bernilai sebesar 6,929. Variabel gaya kepemimpinan $\left(X_{1}\right)$ dengan nilai $-0,315$ yang diartikan tiap naiknya variabel Gaya Kepemimpinan 1 satuan, pada value performa pekerja menurun $-0,315$ satuan dengan variabel lain tetap. Variabel Kedisiplinan $\left(X_{2}\right)$ dengan nilai 0,608 yang diartikan tiap naiknya variabel Kedisiplinan 1 satuan, pada value performa pekerja meningkat 0,608 satuan dengan variabel lain tetap. Variabel Motivasi $\left(X_{3}\right)$ dengan nilai 0,232 yang diartikan tiap naiknya variabel Motivasi 1 satuan, pada value performa pekerja meningkat 0,232 satuan dengan variabel lain tetap.

Tabel 6. Koefisien Determinasi Hipotensi

\begin{tabular}{|c|c|c|c|c|}
\hline \multicolumn{5}{|c|}{ Model Summary } \\
\hline Model & $\mathbf{R}$ & R Square & Adjusted RI Square & $\begin{array}{l}\text { Std. Errorl ofl thel } \\
\text { Estimate }\end{array}$ \\
\hline 1 & $0,847^{a}$ & 0,718 & 0,694 & 2,19622 \\
\hline
\end{tabular}

Berdasarkan tabel $6 . R=0.847$ menunjukkan adanya korelasi yang tinggi antara variabel gaya kepemimpinan, kedisiplinan, motivasi dan kinerja karyawan. Koefisien persegi $R$ adalah 69,4 persen. Hal ini menunjukkan bahwa variasi faktor kinerja karyawan $(Y)$ dapat dijelaskan oleh variabel gaya kepemimpinan (X1), disiplin (X2), dan motivasi (X3). Sisanya 30,6 persen dipengaruhi oleh variabel gratis yang tidak ditemukan. Selanjutnya, dilakukan uji $\mathrm{F}$, hasil uji $\mathrm{F}$ bisa dilihat pada tabel 7 berikut. 
Tabel 7. Uji F

\begin{tabular}{llrrrrr}
\hline \multicolumn{7}{c}{ ANOVA $^{\text {a }}$} \\
\hline Model & & Sum ofl Squares & Df & Meanl Squarel & F & \multicolumn{1}{c}{ Sig. } \\
\hline 1 & Regressionl & 441,134 & 3 & 147,045 & 30,486 &, $000^{\text {b }}$ \\
& Residuall & 173,641 & 36 & 4,823 & & \\
& Totall & 614,775 & 39 & & & \\
\hline
\end{tabular}

a. Dependent Variable: Kinerja Karyawan

b. Predictors: (Constant), Motivasi, Kepemimpinan, Kedisiplinan

Berdasarkan tabel 3.11 terlihat yakni $F_{\text {hitung }}$ senilai 30,486 lebih dari $F_{\text {tabel }}$ yakni 2,86 dengan signifikan $0,000<0,05$. Hasil terkait menunjukkan yakni secara bersama-sama $\mathrm{H}_{1}$ diterima dan $\mathrm{H}_{0}$. Artinya, gaya kepemimpinan $\left(X_{1}\right)$, kedisiplinan $\left(X_{2}\right)$, dan motivasi $\left(X_{3}\right)$ secara serempak dan signifikan berpengaruh terhadap kinerja karyawan (Y) pada PT Pancakarsa Bangun Reksa Medan. Pengujian Hipotesis secara persial (Uji t), hasil uji t disajikan dalam tabel 8.

Tabel 8. Uji t

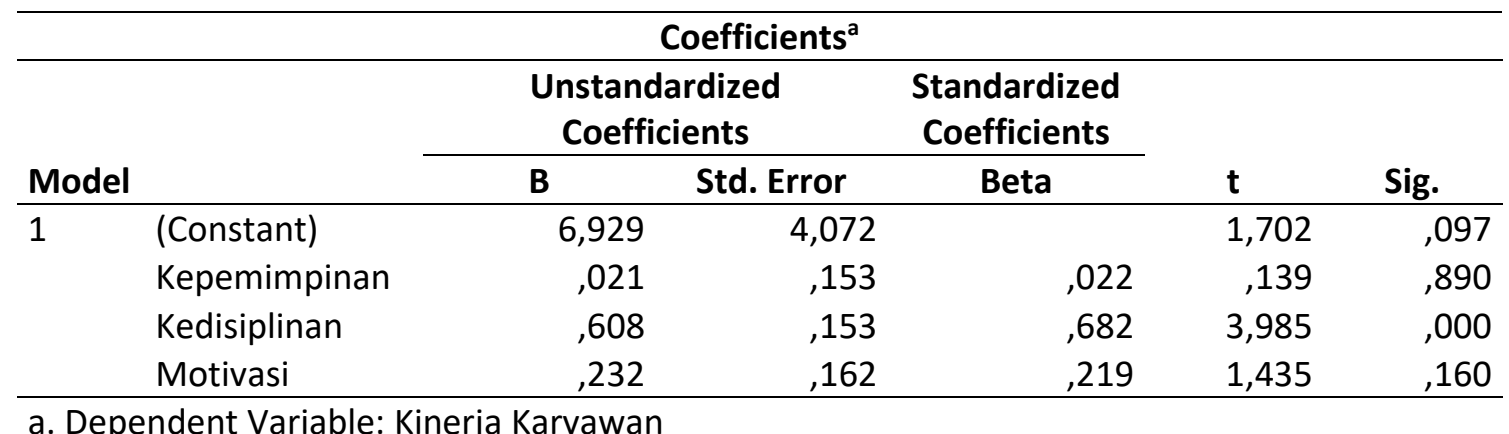

Tabel 8 menunjukkan bahwa uji hipotesis parsial variabel gaya kepemimpinan $\left(\mathrm{X}_{1}\right)$ mempunyai $t_{\text {hitung }}$ sebesar $-0,139$ dengan signifikan 0.890 . Hipotesis $H_{1}$ ditolak karena $t_{\text {hitung }}<t_{\text {tabel }}(-$ $0,139<2,028)$ serta signifikan lebih dari 0,05. Artinya, gaya kepemimpinan $\left(X_{1}\right)$ tidak memiliki pengaruh negatif dan tidak signifikan pada variabel kinerja Karyawan $(\mathrm{Y})$. Uji t variabel kedisiplinan $\left(X_{2}\right)$ memiliki $t_{\text {hitung }} 3.985$ dengan signifikan 0,000 . Hipotesis $H_{2}$ diterima dikarenakan $t_{\text {hitung }}>t_{\text {tabel }}$ $(3,985>2,028)$ serta signifikan kurang dari 0,05 artinya variabel kedisiplinan $\left(X_{1}\right)$ memberi dampak positif dan signifikan pada variabel kinerja karyawan $(\mathrm{Y})$. Uji t variabel motivasi $\left(\mathrm{X}_{3}\right)$ memiliki thitung sebesar 1,435 dengan signifikan 0,160. Hipotesis $H_{3}$ ditolak dikarenakan $t_{\text {hitung }}<t_{\text {tabel }}(0,160<2,028)$ serta signifikan lebih dari 0,05 artinya variabel motivasi $\left(\mathrm{X}_{3}\right)$ tidak berpengaruh dan tidak signifikan pada variabel kinerja karyawan $(\mathrm{Y})$.

\section{Pembahasan}

Temuan pertama, hasil uji secara individual (Uji t) bisa dilihat yakni gaya kepemimpinan $\left(\mathrm{X}_{1}\right)$ memiliki nilai $t_{\text {hitung }}-0,139$ dan nilai $t_{\text {tabel }}$ yakni 2,028 maka nilai $t_{\text {hitung }}<t_{\text {tabel }}(-0,139<2,028)$ dengan nilai signifikannya $0,890>0,05$. Hasil penelitian ini menunjukkan bahwa karakteristik gaya kepemimpinan tidak berpengaruh negatif dan tidak terkait secara substansial dengan indikator kinerja bagi karyawan PT Pancakarsa Bangun Reksa Dana di Medan. Temuan ini diperkuat dengan penelitian sebelumnya yang menyatakan bahwa gaya kepemimpinan tidak berpengaruh negatif dan tidak signifkan terhadap kinerja karyawan (Nur et al., 2020). Ho diterima dan HA ditolak dengan arah pengaruh negatif yang berarti semakin tinggi gaya kepemimpinan di PT. Pancakarsa Bangun Reksa maka semakin rendah kinerja karyawan. Gaya kepemimpinan merupakan suatu cara yang digunakan pemimpin dalam berinteraksi dengan bawahannya (Avilla, 2018). Seorang pemimpin harus menerapkan gaya kepemimpinan untuk mengelola bawahannya karena seorang pemimpin akan sangat memengaruhi keberhasilan organisasi dalam mencapai tujuannya. Semakin tegas gaya 
kepemimpinan seorang pemimpin, maka akan meningkatkan kinerja karyawan (Ariyani, 2016; Azzahrati, 2018). Penyebab gaya kepemimpinan tidak berpengaruh negatif dan tidak signifikan karena kurangnya komunikasi antara pemimpin dan bahawannya. Komunikasi sangat penting karena ini adalah metode utama bagi seorang pemimpin dan anggota dapat bekerja sama dalam melakukan kegiatan perusahaan. Pemimpin harus memiliki kemampuan komunikasi yang efektif. Dengan demikia, seorang pemimpin dapat menyampaikan arahan yang baik kepada bawahannya, sehingga tidak membingungkan dan hasil kinerjanya memuaskan.

Temuan kedua, hasil uji secara individual (Uji t) bisa dilihat yakni kedisiplinan $\left(\mathrm{X}_{2}\right)$ dengan nilai $t_{\text {hitung }} 3,985$ dan nilai $t_{\text {tabel }} 2,028$ maka nilai $t_{\text {hitung }}>t_{\text {tabel }}(2,985>2,028)$ dan signifikannya $0,000<0,05$. Hasil penelitian ini menunjukkan bahwa variabel disiplin memiliki pengaruh yang signifikan dan postif terhadap kualitas kinerja karyawan PT Pancakarsa Bangun Reksa Dana di Medan. Disiplin dapat dipandang memiliki pengaruh pada kinerja karyawan dan efektivitas organisasi. Temuan ini diperkuat dengan penelitian sebelumnya menyatakan bahwa kedisiplinan berpengaruh signifikan pada kinerja karyawan (Catio \& Sunarsi, 2020; Effendi \& Yogie, 2019; Istiqomah \& Suhartini, 2016). Kedisiplinan memberikan dampak positif terhadap performa kinerja karyawan. Kedisiplinan karyawan pada PT Pancakarsa Bangun Reksa sudah cukup baik. Disiplin karyawan sangat penting dalam perusahaan karena dapat memengaruhi kinerja dan citra perusahaan dan memungkinkan tujuan organisasi terpenuhi. Semakin baik disiplin kerja seorang pegawai/karyawan, maka semakin baik hasil kerja (kinerja) yang akan dicapai (Faustyna \& Jumani, 2018; Istiqomah \& Suhartini, 2016). Tanpa dukungan disiplin pegawai yang baik, lembaga atau instansi sulit untuk mewujudkan tujuannya yaitu pencapaian kinerja optimal pegawai. Jadi, disiplin adalah kunci keberhasilan suatu perusahaan dalam mencapai tujuannya.

Temuan ketiga, hasil uji secara individual (Uji t) bisa dilihat yakni Motivasi $\left(\mathrm{X}_{3}\right)$ dengan nilai $t_{\text {hitung }} 1,435$ dan nilai $t_{\text {tabel }}$ yakni 2,028 maka nilai $t_{\text {hitung }}<t_{\text {tabel }}(1,435<2,028)$ dengan nilai signifkannya $0,160>0,05$. Hasil menunjukkan bahwa variabel motivasi tidak berpengaruh serta tidak signifikan pada variabel kinerja karyawan pada PT Pancakarsa Bangun Reksa Medan. Artinya, motivasi tidak berpengaruh terhadap kinerja karyawan. Sejalan dengan temuan penelitian sebelumnya yang menyatakan bahwa motivasi tidak berpengaruh terhadap kinerja karyawan (Dewi, 2021; Pohan, 2019). Kinerja karyawan menurun sebagai konsekuensi dari memotivasi elemen yang tidak berpengaruh dan tidak relevan dengan kinerja karyawan karena karyawan tidak memiliki motivasi, seperti insentif atau tugas yang tidak memadai yang tidak mengimbangi beban kerja. Karyawan tidak termotivasi karena motivasi tidak berpengaruh secara signifikan terhadap kinerja mereka. Sebaiknya, perusahaan lebih memerhatikan motivasi karyawan dengan memberikan kompensasi dalam bentuk penghargaan, tunjangan fasilitas, dan insentif sehingga dapat menumbuhkan semangat karyawan dalam bekerja dan tujuan perusahaan dapat tercapai. Pemberian motivasi merupakan salah satu tujuan agar karyawan yang diberi motivasi dapat bekerja sesuai dengan acuan kerja dan taggung jawab yang diberikan, sehingga tujuan perusahaan dapat tercapai dengan baik (Catio \& Sunarsi, 2020; Wachidah, 2019). Selain itu, juga terkandung unsur-unsur upaya, yaitu upaya yang berkualitas dan diarahkan serta konsisten dengan tujuan-tujuan organisasi yang ingin dicapai. Motivasi seseorang menunjukkan arah tertentu kepadanya dalam mengambil langkah-langkah yang perlu untuk memastikannya sampai pada tujuan.

\section{Simpulan}

Hasil analisis menunjukkan gaya kepemimpinan tidak berpengaruh secara signifikan terhadap kinerja karyawan. Kedisiplinan memiliki pengaruh yang signifikan dan postif terhadap kualitas kinerja karyawan PT Pancakarsa Bangun Reksa Dana di Medan. Motivasi tidak berpengaruh secara signifikan terhadap kinerja karyawan Bank BNI Cabang Manado. Jika motivasi tinggi, kemampuan sangat rendah. maka kinerja juga akan rendah. Penelitian ini memiliki keterbatasan yaitu responden yang digunakan sedikit, sehingga penelitian selanjutnya dapat menggunakan sampel yang lebih banyak lagi. Implikasi penelitian ini diharapkan dapat memberikan dampak bagi perusahaan dalam meningkatkan kinerja karyawannya. 


\section{Daftar Pustaka}

Alhusaini, A., Kritiawan, M., \& Eddy, S. (2020). Pengaruh Motivasi Kerja dan Disiplin Kerja terhadap Kinerja Guru. Jurnal Pendidikan Tambusai, 4(3), 2166-2172. https://doi.org/10.36709/jopspe.v5i1.13326.

Ariyani, R. I. (2016). Pengaruh Gaya Kepemimpinan dan Loyalitas Karyawan terhadap Kinerja Karyawan di Rumah Sakit Islam Hidayatullah Yogyakarta. Jurnal Medicoeticolegal Dan Manajemen Rumah Sakit, 5(2), 136 - 142. https://doi.org/10.18196/jmmr.5118.

Avilla, G. (2018). Gaya Kepemimpinan Transformasional, Keadilan Organisasi, dan Reaksi Karyawan terhadap Kinerja Karyawan. Jurnal Manajemen Dan Pemasaran Jasa, 10(1), 129 - 140. https://doi.org/10.25105/jmpj.v10i1.1670.

Azzahrati, A. (2018). Pengaruh Gaya Kepemimpinan dan Disiplin Kerja terhadap Kinerja Karyawan. AtTadbir : Jurnal Ilmiah Manajemen, 2(1), 46-64. https://doi.org/10.31602/atd.v2i1.1189.

Cahyadi, B. (2019). Pengaruh Gaya Kepemimpinan Dan Lingkungan Kerja terhadap Kinerja Karyawan dalam Perspektif Islam. Amwaluna: Jurnal Ekonomi Dan Keuangan Syariah, 3(1), 29-40. https://doi.org/10.29313/amwaluna.v3i1.4141.

Catio, M., \& Sunarsi, D. (2020). Analisis Pengaruh Kompetensi, Disiplin Kerja, dan Motivasi terhadap Kinerja Guru. Equilibrium: Jurnl Pelatihan Pendidikan Dan Ekonomi, 17(02), 16-26. https://doi.org/10.25134/equi.v17i02.ABSTRACT.

Dewi, N. N. (2021). Pengaruh Motivasi Disiplin Kerja dan Pengawasan terhadap Kinerja. Aksara: Jurnal IImu Pendidikan Nonformal, 7(2), 355. https://doi.org/10.37905/aksara.7.2.355366.2021.

Effendi, M., \& Yogie, F. (2019). Pengaruh Motivasi dan Disiplin Kerja terhadap Kinerja Karyawan. Journal of Management and Bussines (JOMB), 1(1), 88-98. https://doi.org/10.31539/jomb.v1i1.654.

Farhah, A., Ahiri, J., \& Ilham, M. (2020). Pengaruh Motivasi Kerja dan Disiplin Kerja terhadap Kinerja Karyawan. Jurnal Online Program Studi Pendidikan Ekonomi, 5(1), 1. https://doi.org/10.36709/jopspe.v5i1.13326.

Faustyna, \& Jumani. (2018). Pengaruh Pengembangan Karir dan Disiplin Kerja terhadap Kinerja Karyawan pada PT Pelabuhan Indonesia I (Persero) Medan. Jurnal IImiah Manajemen Dan Bisnis, 15(1). https://doi.org/10.30596/jimb.v15i1.970.

Gailea, N. Y., Sendow, G. M., \& Uhing, Y. (2018). Pengaruh Budaya Kerja, Kepribadian dan Self Esteem terhadap Kinerja Karyawan pada Dinas Energi dan Sumber Daya Mineral Daerah Provinsi Sulawesi Utara. EMBA, 6(4), 2048-2057.

Gandung, M., \& Suwanto, S. (2020). Analisis Pengaruh Kompensasi dan Gaya Kepemimpinan terhadap Kinerja Karyawan pada PT Surya Rasa Loka Jaya di Jakarta Barat. JENIUS (Jurnal Ilmiah Manajemen Sumber Daya Manusia), 3(3), 236 - 245. https://doi.org/10.32493/JJSDM.v3i3.4861.

Hardono, Haryono, A. Y. (2017). Kepemimpinan Kepala Sekolah, Supervisi Akademik , dan Motivasi Kerja dalam Meningkatkan Kinerja Guru. Jurnal Unnes, 6(1), 1-8.

Hasibuan, N. \&. (2019). Kepemimpinan Pendidikan dalam Perspektif Hadis Telaah Historis Filosofi. KENCANA.

Istiqomah, S. N., \& Suhartini. (2016). Pengaruh Disiplin Kerja dan Iklim Komunikasi terhadap Kinerja Pegawai Dinas Perhubungan Kota Yogyakarta, dengan Motivasi Kerja sebagai Variabel Intervening. Jurnal Siasat Bisnis, 19(1), 89 - 97. https://doi.org/10.20885/jsb.vol19.iss1.art8.

Mahriani, E. (2018). Pengaruh Stres dan Disiplin Kerja Karyawan terhadap Kepuasan dan Kinerja Karyawan PT Bank Perkreditan Rakyat (BPR) Mitrathama Arthabuana di Kabupaten Banjar. Jurnal Studi Ekonomi, 9(1), 38-46. https://doi.org/10.18592/at-taradhi.v9i1.2120.

Nugroho, R. E. (2019). Pengaruh Gaya Kepemimpinan Transformasional Stress Kerja dan Budaya Organisasi terhadap Kinerja Karyawan Kontrak Proyek. Jurnal Ilmiah Manajemen, 9(2), 341 354. https://doi.org/10.22441/mix.2019.v9i2.007.

Nur, M., Nurkaidah, N., \& Nonci, N. (2020). Gaya Kepemimpinan dan Sumber Daya Manusia terhadap 
Kinerja Pegawai pada Kantor Sekretariat Daerah Kabupaten Majene. Jurnal Paradigma Administrasi Negara, 2(1), 24-31. https://journal.unibos.ac.id/paradigma/article/view/107.

Pohan, R. (2019). Pengaruh Iklim Kerja dan Motivasi terhadap Kinerja Guru Madrasah Tsanawiyah Negeri Kota Pekanbaru. Jurnal Riset Dan Kajian Pendidikan Agama Islam, 2(1), 1-22. https://doi.org/10.24014/au.v2i1.6680.

Prabowo, A. N. (2019). Analisis Kinerja Karyawan (Studi Kasus pada CV. RESTU Kota Banjar). Jurnal Ekonomi, Bisnis Dan Manajemen Daulat Rakyat Urnal Ekonomi, Bisnis Dan Manajemen Daulat Rakyat, 3(1), 43 - 53. https://doi.org/10.26460/mmud.v3i1.4322.

Rofiliana, L., \& Rofiuddin, M. (2021). Faktor-faktor yang mempengaruhi kinerja karyawan Bank Syariah Indonesia. Journal of Management and Digital Business, 1(1), 1-12. https://doi.org/10.53088/jmdb.v1i1.26.

Sari, M., \& Masruroh, F. (2018). Pengaruh Motivasi Dan Disiplin Kerja Terhadap Kinerja Pegawai Di Kecamatan Magelang Tengah Kota Magelang. Jurnal Mahasiswa Administrasi Negara (JMAN), 02(02), 36-51.

Siska, A. J. (2018). Pengaruh Disiplin dan Motivasi Kerja terhadap Kinerja Guru pada SMAN 1 Canduang Kabupaten Agam. Jurnal Sosial Dan Ilmu Ekonomi, 3(2), 98-103.

Sudarso, A. P. (2017). Analisis Pengaruh Gaya Kepemimpinan dan Insentif terhadap Kinerja Karyawan pada Yayasan Pendidikan Mulia Buana. JENIUS (Jurnal IImiah Manajemen Sumber Daya Manusia), 1(1). https://doi.org/10.32493/jjsdm.v1i1.659.

Sya'roni, Herlambang, T., \& Cahyono, D. (2018). Dampak Motivasi, Disiplin Kerja dan Kepemimpinan Kepala Sekolah terhadap Kinerja Guru. Jurnal Sains Manajemen Dan Bisnis Indonesia, 8(2), 131-147. https://doi.org/10.32528/jsmbi.v8i2.1785.

Wachidah, N. (2019). Pengaruh Sikap Inovatif, Kedisiplinan dan Motivasi Kerja terhadap Kinerja Guru SMP Negeri. Journal of Educational Evaluation Studies (JEES), 1(1), 57-63.

Widelia, K., Yusiana, R., \& Widodo, A. (2016). Pengaruh Green Marketing dan Corporate Social Responsibility terhadap Keputusan Pembelian Produk Unilever ( Studi Kasus Masyarakat Kota Bandung ). ECODEMICA, 3(2), 539-550. https://doi.org/10.23917/benefit.v19i2.2316.

Widyawati, S. R., \& Karwini, N. K. (2018). Pengaruh Self Ssteem, Self Efficacy dan Keterlibatan Kerja terhadap Kinerja Karyawan pada PT Dwi Fajar Semesta Denpasar. Forum Manajemen STIMI Handayani Denpasar, 16(2), 54-64. 